\title{
Improving Students' Conceptual Understanding Through Geogebra-Assisted "5E" Learning Cycle: Is It Effective?
}

\author{
Ni Nyoman Wulan Darma Putri ${ }^{*}$, I Wayan Puja Astawa², I Made Ardana ${ }^{3}$ iD \\ ${ }^{1,2,3}$ Ganesha University of Education, Singaraja, Indonesia \\ *Corresponding author: wulan.darmaputri@gmail.com
}

\begin{abstract}
This study aims to investigate the effectiveness of GeoGebra-assisted 5E Learning Cycle model toward student's understanding of mathematical concept with control of student's prior knowledge. This study was a quasi-experiment with post-test only control group design. The population of the study was 324 ninth grader students where 81 of them were selected as sample through cluster random sampling technique. The data collected in this study were student's mathematical prior knowledge obtained by giving objective tests before starting the learning process and data of student's mathematical conceptual understanding obtained by giving an essay test at the end of learning process. The hypotheses were tested using t-test and one-way analysis of covariance test. The results showed that: the usage of GeoGebra-assisted 5E Learning Cycle Model has a positive impact toward student's understanding of mathematical concept, where $t=2,977$ and $p=0,002$; the usage of GeoGebra-assisted 5E Learning Cycle Model has a positive impact toward student's understanding of mathematical concept after the prior knowledge variable was controlled, where $F=31,880$ and $p=0,000$. The findings of this research implied that GeoGebra-assisted 5E Learning Cycle Model can be used as an alternative learning model in an effort to improve students' understanding of mathematical concepts.
\end{abstract}

Keywords: 5E Learning Cycle, Geogebra, Conceptual Understanding

History:
Received : 4 June 2020
Revised $\quad$ : 1 September 2020
Accepted : 26 October 2020
Published : 4 April 2021

\section{Introduction}

Concepts are the substance of mathematical knowledge (Burhanzade \& Aygör, 2014; Simon, 2017). Students can make sense of mathematics only if they understand its concepts and their meanings or interpretations. A mathematical concept is knowledge of the mathematical necessity of a particular mathematical relationship (Simon, 2017; Smith et al., 2018; Sukardjo \& Salam, 2020). This means in order to understand knowledge that we have learned previously, a particular relationship must exist. For example, students who can identify prime numbers understand how to find factors of numbers (Bahr \& Rieth, 1989; Simon, 2017).

The National Research Council explains the importance of conceptual understanding. Some points to consider include: students with the understanding of the concept of knowing more than just isolated facts understand why mathematical ideas are important and useful in context. Knowledge is coherently arranged to enable students to learn new concepts by connecting the concepts with what they already know. Conceptual understanding supports retention or memory because of facts and methods learned with connected understandings so that students are easier to remember, use and reconstruct the concept. Knowledge learned with understanding provides the basis for generating new knowledge and for solving new 
problems. When students understand a concept, they can extend the concept to new areas, and conceptual understanding helps students in solving problems. Therefore, learning mathematics should be more focused on conceptual understanding (Amir, 2013; Kodariyati \& Astuti, 2016; Nurhusain, 2017).

Understanding the concept of mathematics becomes an important key to solve the mathematical and real-world problems. However, in fact, the lack of students' understanding of mathematical concepts is still one of the main issues in learning mathematics. Trends in International Mathematics and Science Study (TIMSS) 2015 compared the mathematical and science achievement of students from various countries in the world, one of them is Indonesia (Mullis et al., 2016). The results of the study showed that students' mathematics achievement in Indonesia is ranked $44^{\text {th }}$ out of the 49 participating countries. Meanwhile, the results of the Program for International Student Assessment (PISA) 2015, a survey that assessed reading, science and mathematics skills showed that Indonesia is in position 62 of 70 countries (Odell et al., 2021).

There are some factors that contributed to the lack of student's understanding of concepts. First, the paradigm of mathematics learning in schools is still dominated by the oldstyle learning in which the expository method becomes the teacher's top choice and the highest authority rests with the teacher (Chazan et al., 2008; Xin et al., 2020). The approach and the learning model used do not provide opportunities for students to explore and explore concepts. In addition, the lack of use of visual aids and learning media can also hinder the understanding of mathematical concepts that will ultimately affect the next learning process. In accordance with constructivism ideology, learning is not just a transfer of knowledge but students must play an active role in building knowledge by giving meaning to that knowledge. The cognitive approach focuses on making knowledge meaningful and helping learners organize and relate new information to prior knowledge in memory (Ionas et al., 2012; Purwati, 2016; Yilmaz et al., 2020).

Learning mathematics is a psychological process of active activity in an individual's attempt to understand or master mathematical concepts. The ability to understand mathematics can be developed if the learning process supports the active involvement of students to explore and discover new things that develop students' minds. Students will be able to understand and interpret the concept better if in the learning process where students take place allows students to engage in discussion, elaboration and explanation (Nurhusain, 2017; Widodo \& Kartikasari, 2017). Teachers need to design a learning that can generate the potential of students in using their ability to think actively to understand the concept of mathematics. To be able to increase students' learning activities and understanding of mathematical concepts, it is necessary to design a specific and systematic learning model where the activities are student-centered. One of the most effective learning models to achieve this goal is the 5E Learning Cycle Model (Plaikoil et al., 2019; Qawasmeh \& Syouf., 2017).

The 5E Learning Cycle Model conforms to constructivism theory, where learning can provide learners with a broad opportunity to develop thinking skills, interact with learning environments, conduct investigations, discover concepts, communicate, use concepts and ideas in new situations, develop skills and evaluate the learning process. Several studies have found the positive effects of this model on conceptual understanding, learning achievement, problem-solving skills, and critical thinking skills (Cahyarini et al., 2016; Plaikoil et al., 2019; Putra et al., 2018; Tuna \& Kaçar, 2013). Each phase of this learning is student-centered so as to prevent students from learning that tends to memorize rather than comprehend, and can increase learning motivation because students are actively involved in the learning process. 
Along with the rapid development of technology, computer programs are ideal for use as a medium to teach math concepts. Learning mathematics using technology provides new learning opportunities that potentially engage students with a variety of mathematical skills and level of understanding through task and mathematical activities (Adelabu et al., 2019; Scanlon et al., 2011). In addition, visualization and exploration of mathematical objects and concepts in a multimedia environment can encourage understanding in new ways. The rapid development of computer technology provides widespread opportunities for human beings to use it in various ways, including improving the effectiveness of learning. In Mathematics classroom, the use of technology helps learners to perform better calculations, analyze data and enhances the exploration of mathematics concepts, thus resulting in permanent and effective learning in Mathematics (Adelabu et al., 2019; Bayram et al., 2013). To be able to learn abstract mathematics concepts, it is necessary to consider the condition of the learners themselves. Mathematics education in junior high schools, in a variety of ways, can be a bridge that connects concrete mathematics learning in elementary school and formal math in high school. One of the transitions that play an important role is in studying geometry (Ariawan, 2014). Thus, it is important for students in grades seven to nine to explore the concept of geometry to build the foundation for further formal learning.

According to Duval (1998), learning geometry involves three kinds of cognitive processes. Those processes are the visualization process, the construction process and the reasoning process. These three processes must be emerged in learning because the synergies of these three cognitive processes are necessary conditions in studying geometry (Ariawan, 2014). GeoGebra is a dynamic software that combines geometry, algebra and calculus (Adelabu et al., 2019; Anghileri, 2006; Ariawan, 2014). GeoGebra in mathematics learning can be utilized as: (1) media for demonstration and visualization, (2) construction aids, (3) mathematical concept finding tools. GeoGebra will provide students with direct experience in learning geometry. This computer program can be a means for students to explore. GeoGebra with its visualization features allows students to gain a better understanding of mathematical concepts.

This visualization is a vital phase that can help students to bridge the gap between abstract mathematics learning experiences and their concrete knowledge. Visuals help break down abstract math concepts leading to better understanding and comprehension and advanced mathematical skills (Eveline et al., 2019; Litke, 2020). Visual learning tools and strategies can make a difference in student's level of understanding in mathematics. It can increase the learning potential of all students along with their ability to acquire and communicate mathematical concepts. Computer simulations presents many abstract things that are difficult to think of. It provides dynamic ways of representing and manipulating geometric objects that are not possible with paper, pencil, compass, and straightedge alone (Lashley, 2017; Ozdag \& Aygor, 2012). This of course will further simplify the students' minds in understanding mathematics. Thus, the collaboration between GeoGebra with 5E Learning Cycle model is expected to improve students' understanding of mathematical concepts.

This study aims to investigate the effectiveness of GeoGebra-assisted 5E Learning Cycle model toward student's understanding of mathematical concept. Considering the role of prior knowledge on students 'understanding, students' ability in understanding mathematical concepts is thought to be influenced by the level of prior knowledge of the students. Based on the explanation above, to know the effectiveness of GeoGebra-assisted $5 \mathrm{E}$ Learning Cycle model to student's understanding of mathematical concepts, it is necessary to control the students' prior knowledge score so that the effect can be believed solely due to the applied learning model. 


\section{Materials and Methods}

This research was a quantitative research using quasi experiment method; the purpose was to see the effect of different treatment given to different groups. The experimental group of this study used the GeoGebra-assisted 5E Learning Cycle model, while the control group used conventional learning, which is cooperative learning. The same course content and intensity of learning was given to both groups. The research design used in this study was post-test design only control group design. Data on the student's understanding of concepts were obtained through an essay test at the end of the study, while data on student's prior knowledge were obtained through multiple-choice tests before the learning began. The population in this study was all ninth-grade students of SMPN 3 Denpasar academic year 2017/2018 distributed into eight academically homogeneous classes. Two classes were drawn randomly as samples. This method was used because the units in the population were classes that were groups of individuals. In other words, those who got the same opportunity to become samples were not individual students, but students as groups distributed into classes (Suryabrata, 2014).

Sample equality testing was conducted to convince the two sample groups were completely equal. Equivalence of the sample was tested based on the mid term test score using $t$ test at 5\% significance level. Based on the $t$ test, it is obtained that $t$ value equal to 0.176 which is less than $t$ table value at 1.990. In addition, the $p$ value was obtained by 0.861 . This value is greater than the predetermined error rate of 0.05 . Therefore, it was concluded that the difference between the two classes was not significant, or in other words, the two sample classes were equivalent. The variables involved in this research were: (1) the learning model as the independent variable which was GeoGebra-assisted 5E Learning Cycle Model with the comparison of the conventional model, (2) the student's mathematics prior knowledge as the control variable whose effect on the dependent variable is controlled, and (3) student's understanding of mathematical concepts as dependent variable. The data collected in this study were data on student's prior knowledge and understanding of mathematical concepts. Data collection is done by test method. Data on the student's prior knowledge were collected before implementing the learning model, and the data on student's understanding of mathematical concepts were collected at the end of the study after the learning process was completed. The test instrument must first be analyzed for its validity, reliability, difficulty index and distinguishing power. The hypotheses were tested using t-test and one-way analysis of covariance test.

\section{Results and Discussion Results}

There were two hypotheses tested in this study. The first hypothesis was that there is a positive influence of the application of the GeoGebra-assisted 5E Learning Cycle Model to the students' understanding of mathematical concepts. The first hypothesis testing was performed using right- $t$ test. The significance value obtained at the error level of $5 \%$ was compared to conclude whether there is a significant difference or not. If $s i g<0,05$ it can be interpreted that the hypothesis $H_{0}$ is rejected and $H_{1}$ is accepted. The results of the t-test calculations for the first hypothesis are shown in the Table 1.

Based on the tests that were done, the statistical value of $t$ equal to 2.977 with $p$ value of 0.002 was obtained. The value of the corresponding $t_{\text {table }}$ is 1.664 . The result indicates that $t_{\text {count }}>t_{\text {table }}$ and $p$ value was less than the specified error rate of 0.05 . Thus, the decision was made to reject $H_{0}$, which means there is a difference in students' understanding towards mathematical concepts between groups of students who took learning using GeoGebraassisted 5E Learning Cycle Model and groups of students who took conventional learning. 
Table 1. T-Test Results from the First Hypothesis

\begin{tabular}{|c|c|c|c|c|c|c|c|c|c|c|}
\hline \multicolumn{6}{|c|}{$\begin{array}{c}\text { Levene's Test for Equality of } \\
\text { Variances }\end{array}$} & \multicolumn{5}{|c|}{ t-test for Equality of Means } \\
\hline & & \multirow[b]{2}{*}{$\mathrm{F}$} & \multirow[b]{2}{*}{ Sig. } & \multirow[b]{2}{*}{$\mathrm{t}$} & \multirow[b]{2}{*}{$\mathrm{df}$} & \multirow{2}{*}{$\begin{array}{c}\text { Sig. } \\
(2- \\
\text { tailed) }\end{array}$} & \multirow{2}{*}{$\begin{array}{l}\text { Mean } \\
\text { Differ } \\
\text { ence }\end{array}$} & \multirow{2}{*}{$\begin{array}{c}\text { Std. } \\
\text { Error } \\
\text { Differenc } \\
\text { e }\end{array}$} & \multicolumn{2}{|c|}{$\begin{array}{l}95 \% \text { Confidence } \\
\text { Interval of the } \\
\text { Difference }\end{array}$} \\
\hline & & & & & & & & & Lower & Upper \\
\hline \multirow[t]{2}{*}{$\begin{array}{l}\text { Concept } \\
\text { Understan } \\
\text { ding }\end{array}$} & $\begin{array}{l}\text { Equal } \\
\text { variances } \\
\text { assumed }\end{array}$ & 0.009 & 0.93 & 2.977 & 79 & 0.004 & 4,640 & 1.559 & 1.538 & 7.742 \\
\hline & $\begin{array}{l}\text { Equal } \\
\text { variances } \\
\text { not } \\
\text { assumed }\end{array}$ & & & 2.977 & $\begin{array}{r}78.9 \\
20\end{array}$ & 0.004 & 4.640 & 1.559 & 1.538 & 7.743 \\
\hline
\end{tabular}

An analysis of descriptive was done and the result showed that the average score of mathematical concepts comprehension of students who learned using the GeoGebra-assisted 5E Learning Cycle Learning Model was 38.39. This value was higher than the group of students who were taught by conventional learning that was 33.75. In other words, the application of learning using GeoGebra-assisted 5E Learning Cycle Model was superior compared to conventional learning in terms of achieving the understanding of mathematical concepts.

The second hypothesis tested was the application of GeoGebra-assisted 5E Learning Cycle Model to positively influence the understanding of mathematical concepts after the initial knowledge of the students was controlled. The hypothesis was tested using analysis of covariance. To be able to conclude whether there is a significant difference or not, comparing the significance value obtained at the error level of $5 \%$ was done. If $s i g<0,05$, it can be interpreted that the $H_{0}$ is rejected and $H_{1}$ is accepted. The results of the F-test calculations for the second hypothesis can be seen in Table 2.

Table 2. Results of Covariance Analysis from the Second Hypothesis

\begin{tabular}{lccccc}
\hline \multicolumn{1}{c}{ Source } & Type III Sum of Squares & df & Mean Square & F & Sig. \\
\hline Corrected Model & $4071.284^{\mathrm{a}}$ & 2 & 2035.642 & 635.310 & .000 \\
Intercept & 32.035 & 1 & 32.035 & 9.998 & .002 \\
$\mathrm{X}$ & 3635.331 & 1 & 3635.331 & 1134.561 & .000 \\
$\mathrm{~A}$ & 102.150 & 1 & 102.150 & 31.880 & .000 \\
Error & 249.926 & 78 & 3.204 & & \\
Total & 109874.000 & 81 & & & \\
\hline Corrected Total & 4321.210 & 80 & & &
\end{tabular}

${ }^{\mathrm{a}} \mathrm{R}$ Squared $=.942($ Adjusted R Squared $=.941)$

The tests that were done resulted the value of $F=31.880$ and $p=0.000$. The $F_{\text {table }}$ value is 3.11 and the default error rate is 0.05 . Thus, $F_{\text {count }}>F_{\text {table }}$ and $p<0.05$. These results served as the basis for making a decision to reject $H_{0}$, or in other words the application of the GeoGebra-assisted 5E Learning Cycle Model had a positive effect on the understanding of mathematical concepts after the prior knowledge of the controlled students.

The average obtained after controlling for covariance of initial knowledge is presented in the Table 3. It can be seen that the average level of concept understanding for students 
from the experimental class was 37.225 where this value was greater than the average understanding of the control group concept of 34.944 .

Table 3. Estimated Marginal Means

\begin{tabular}{ccccc}
\hline \multirow{2}{*}{ Class } & \multirow{2}{*}{ Mean } & \multirow{2}{*}{ Std. Error } & \multicolumn{2}{c}{ 95\% Confidence Interval } \\
\cline { 4 - 5 } & & & Lower Bound & Upper Bound \\
\hline Experiment & $37.225^{\mathrm{a}}$ & .282 & 36.664 & 37.786 \\
Controlled & $34.944^{\mathrm{a}}$ & .285 & 34.376 & 35.512 \\
\hline
\end{tabular}

Based on the analysis, it can be concluded that there are differences in understanding mathematical concepts between groups of students who took part in learning using GeoGebra-assisted 5E Learning Cycle Model and groups of students who took conventional learning after students' initial knowledge was controlled.

\section{Discussion}

The understanding of mathematics concept is one of the important goals in learning. Along with the ability to understand the concept, the material learned by the students is not merely a recitation but it is more than that. Students are able to understand better about the concept of the subject matter itself by being able to express it again in another form that is easy to understand and apply it in accordance with its cognitive structure. In general, the differences that occur in the students' understanding of mathematical concepts can be caused by the stages of systematic learning that have been arranged in such a way that the process can provide an opportunity for students to construct their understanding independently.

The stage or phase begins with Engage. The purpose of this phase is to help students focus on topics learned and make connections to student previous learning experiences. Teachers provide inducement questions that can motivate and activate students' reasoning about learned concepts. It should be noted that when asking questions, teachers avoid defining and explaining concepts. Bybee (2014) states that successful engagement results in students being puzzled by, and actively motivated in the learning activity. Students have some ideas, but the expression of concepts and use of their abilities may not be scientifically accurate and productive. This stimulus will lead students into the Explore stage, a phase in which students use concrete experiences to observe, gather information, test and reformulate hypotheses. In this phase, students try to solve the problem given by working, discussing and exploring in groups. Students were involved in active learning activities that allow them to examine the adequacy of their prior conceptions, test their hypotheses or predictions. This led to disequilibrium where predictions based on their prior beliefs were contradicted. Students are encouraged to discuss the conception with their group mates and assign decision in order to construct more appropriate concept.

The importance of the visualization aspect in mathematics learning is emphasized in this phase. Support from GeoGebra as a dynamic manipulative learning medium is able to facilitate students to improve their interpretation of a mathematical concept. Dynamic geometry environments provide ways of representing and manipulating geometric objects. Adelabu et al. (2019) states that these various environments allow different opportunities for learners to employ with geometric objects and their procedures. In addition, the environments have the potential to help learners develop different understandings of many properties and theorems. Some of the advantages of using GeoGebra in learning that involves the concept of geometry particularly include: (1) Produce geometric visualization faster and more accurate than using pencil or ruler. Thus, calibration errors can be avoided and students are facilitated in constructing geometry builds. (2) The existence of animation facilities and manipulation movements in the GeoGebra program can provide a clearer visual experience to the students 
in understanding the geometry concept. (3) The feedback provided helps students in verifying their own understanding. (4) Facilitate students to investigate or demonstrate the properties that apply to a geometry object.

Furthermore, in the Explain phase students are encouraged to explain the concepts that have been obtained from exploratory results with their own sentences, to prove and clarify their explanations, and to compare their arguments with the arguments of other students. Therefore, the synergies of these three phases can optimize the conceptual understanding indicator that is related to the ability to express the concept in its own sentence. While the phase of Explore and Explain optimize students' ability to identify concepts or give examples. The new knowledge they have gained is then implemented in the Elaborate phase through practice questions. Using new concepts in different situations or applications related to required concepts can incorporate concepts into long-term memory. Furthermore, it is important for students to use the skills they have acquired and evaluate their understanding. This Evaluate stage encourages students to assess their understanding and abilities and provides opportunities for teachers to evaluate student progress to achieve learning objectives. Based on this, the third conceptual understanding indicator relating to students' ability to apply concepts in various situations can be optimized through student activities in the Elaborate and Evaluate phases.

This discovery also supports the results of previous studies. The results of research conducted in the field of science shows that the computerized 5E model is very efficient in teaching the concept of science to students compared to using a traditional model (Piyayodilokchai et al., 2013; Plaikoil et al., 2019; Qawasmeh \& Syouf, 2017). According to Qawasmeh \& Syouf (2017), one of them is due to a logical and interesting sequence in presenting educational materials with continuous evaluation, so that rapid feedback continues to encourage students to acquire and learn concepts. In addition, the interaction between computerized 5E model with students can reduce the boredom level of students, thus helping them to study in longer time, so that students can learn more scientific concepts more meaningfully. Piyayodilokchai et al. (2013) found that the 5E learning cycle model-based learning unit with the instructional interactive multimedia significantly outperformed the $5 \mathrm{E}$ learning cycle model instruction and the traditional method in promoting students' understanding of key aspects and concepts involved in Structured Query Language (SQL), especially regarding basic knowledge of SQL and ability to apply SQL on the students' projects on the database system.

This study indicated the positive effect of integrating interactive multimedia with a learning approach on students' understanding. In the GeoGebra-assisted 5E Learning Cycle Model, teacher's tendency to deliver materials with lectures will decrease. Students can be more freely in constructing their understanding by working together in groups. Students are demanded to try harder to find the concept independently through learning that has been designed by the teachers. This is also supported by field findings during the learning process using the GeoGebra-assisted 5E Learning Cycle Model. Students demonstrate liveliness in the learning process. Students tend to ask more questions either when in groups or when discussions are classical and more courageous in conveying their opinions. According to NCTM (2014), the use of mathematical tools and technology as essential resources help students learn and make sense of mathematical ideas, reason mathematically, and communicate their mathematical thinking. It also helps students visualize and concretize mathematics abstractions. In addition, when these resources are used appropriately, they support effective teaching and meaningful learning.

The GeoGebra-assisted 5E Learning Cycle Model requires students to take full responsibility for learning activities and students are given the opportunity to develop their activities and mindset optimally. In contrast, conventional learning models tend to limit the 
flexibility of students in exploring concepts. Conventional learning has so far emphasized the process of receiving knowledge compared to the search process and knowledge construction. This leads to an understanding of student concepts learned by using the GeoGebra- assisted 5E Learning Cycle Model higher than students who follow conventional learning. The prior knowledge of students is one of the internal factors that affect the learning process of students because the prior knowledge can describe the readiness of students in following a lesson. Prior knowledge is also viewed as relevant knowledge held at the time begin to follow a learning subject so that it can be said that the initial knowledge is a prerequisite that must be mastered before the students follow a learning activity. Prior knowledge acts as a mental hook for the acquisition of new information and as the basic foundation of conceptualization and skill construct.

There are lot of researches have shown that mathematics learning should be based on existing student knowledge along with teaching computational thinking. This is because students often have relevant information that can assist them in mastering new content. If computational thinking is embedded across multiple subject areas, it has additional advantages, such as helping students to make powerful connections between their classes and beyond and have a rich toolkit to draw from that crosses traditional subject borders when faced with problems that are difficult to categorize within a traditional subject area (Ionas et al., 2012; Purwati, 2016). Deep learning occurs as the students learn to persevere, collaborate, and rely on the computational thinking process (Lashley, 2017). Purwati (2016) reveals another finding on the role of early knowledge on conceptual understanding. The data analysis performed shows that the initial knowledge and concept comprehension have a positive relationship with the contribution of $43.3 \%$.

Regardless of the influence of the prior knowledge on conceptual understanding, the results of this study indicate that when controlling the scores of students' mathematics prior knowledge, the conceptual understanding differences between control and experimental groups persist. This means that the GeoGebra-assisted 5E Learning Cycle Model continues to have an effect on understanding the mathematical concepts of students regardless of the level of initial knowledge students have. The mean score of understanding of mathematical concepts between students of the experimental class and the students of the control class after the controlled prior knowledge score was 37.225. This score was higher than the average understanding of the control group concept of 34.944. The average difference in the comprehension scores of mathematical concepts between students of the experimental class and the students of the control class after the controlled prior knowledge score showed that the GeoGebra-assisted 5E Learning Cycle Model consistently had a positive influence on students' conceptual understanding. This is because the constructivist learning approach motivates students to learn a topic by engaging in several learning phases, where each phase has a specific function and contributes to the learner's formulation of a better understanding of mathematical concepts.

\section{Conclusion}

The research findings as described above have implications for learning especially in the achievement of mathematical concepts. The GeoGebra-assisted 5E Learning Cycle Model can be used as an alternative learning model to improve students' understanding of mathematical concepts. The selection of activities and worksheets to be used in learning using the GeoGebra-assisted 5E Learning Cycle Model should be done carefully, where the material should be interactive, attractive, and appropriate to the cognitive level of the students and should provide opportunities for the students to construct their own understanding. This study suggests that basic skills and knowledge of computer use are essential. Mathematics 
teachers should be trained beyond basic skills of computer to effectively and confidently use dynamic computer software.

\section{References}

Adelabu, F. ., Makgato, M., \& Ramaligela, M. S. (2019). The Importance of Dynamic Geometry Computer Software on Learners' Performance in Geometry. The Electronic Journal of E-Learning, 17(1), 52-63. https://files.eric.ed.gov/fulltext/EJ1216699.pdf.

Amir, A. (2013). Pembelajaran matematika dengan menggunakan kecerdasan majemuk (multiple intelligences). Logaritma: Jurnal Ilmu-Ilmu Pendidikan Dan Sains, 1(1). https://doi.org/10.24952/logaritma.v1i01.196.

Anghileri, J. (2006). Scaffolding Practices that Enhance Mathematics Learning. Journal of Mathematics Teacher Education, 9, 33-52. https://doi.org/10.1007/s10857-006-90059.

Ariawan, I. P. W. (2014). Pengembangan LKM Multi Representasi Berbantuan GeoGebra Untuk Meningkatkan Kemampuan Berpikir Kritis Mahasiswa. Jurnal Pendidikan Indonesia, 3(1). https://ejournal.undiksha.ac.id/index.php/JPI/article/view/2918.

Bahr, C. M., \& Rieth, H. J. (1989). The effects of Instructional Computer Games and Drill and Practice Software on Learning Disabled Students' Mathematics Achievement. Computers in the Schools, 6(4), 87-102.

Bayram, Z., Oskay, Ö. Ö., Erdem, E., Özgür, S. D., \& Şen, Ş. (2013). Effect of Inquiry based Learning Method on Students' Motivation. Procedia - Social and Behavioral Sciences, 106, 988-996. https://doi.org/10.1016/j.sbspro.2013.12.112.

Burhanzade, H., \& Aygör, N. (2014). Problems that the students face while solving 1 st Degree Equations with two Unknown, during their prepare to the High School Entrance Exam ( SBS ). Procedia - Social and Behavioral Sciences, 122, 477-483. https://doi.org/10.1016/j.sbspro.2014.01.1378.

Bybee, R. W. (2014). The BSCS 5E Instructional Model: Personal reflections and contemporary implications. Science and Children, 51(8), 10-13. https://education.sdsu.edu/dle/resources/05329-

5E_instructional_Model_R_Bybee.pdf.

Cahyarini, A., Rahayu, S., \& Yahmin. (2016). The Effect of 5E Learning Cycle Instructional Model Using Socioscientific Issues (SSI) Learning Context on Students' Critical Thinking. Jurnal Pendidikan IPA Indonesia, 5(2), 222-229. https://doi.org/10.15294/jpii.v5i2.7683.

Chazan, D., Yerushalmy, M., \& Leikin, R. (2008). The Journal of Mathematical Behavior An analytic conception of equation and teachers 'views of school algebra. 27, 87-100. https://doi.org/10.1016/j.jmathb.2008.07.003.

Duval, R. (1998). Geometry from a Cognitive Point of View in Perspective on the Teaching of Geometry for the 21st Century. Kluwer Academic Publishers.

Eveline, E., Jumadi, Wilujeng, I., \& Kuswanto, H. (2019). The Effect of Scaffolding Approach Assisted by PhET Simulation on Students' Conceptual Understanding and Students' Learning Independence in Physics. Journal of Physics: Conference Series. https://doi.org/10.1088/1742-6596/1233/1/012036.

Ionas, I. G., Cernusca, D., \& Collier, H. L. (2012). Prior knowledge influence on selfexplanation effectiveness when solving problems: an exploratory study in science learning. International Journal of Teaching and Learning in Higher Education, 24(3), 349-358. http://www.isetl.org/ijtlhe/.

Kodariyati, L., \& Astuti, B. (2016). Pengaruh Model PBL Terhadap Kemampuan Komunikasi dan Pemecahan Masalah Matematika Siswa Kelas V SD. Jurnal Prima Edukasia, 4(1), 93-106. https://doi.org/10.21831/jpe.v4i1.7713. 
Lashley, L. (2017). The Effects of Computer-Aided Instruction in Mathematics on the Performance of Grade 4 Pupils. SAGE Open. https://doi.org/10.1177/2158244017712775.

Litke, E. (2020). Instructional practice in algebra : Building from existing practices to inform an incremental improvement approach. Teaching and Teacher Education, xxxx, 103030. https://doi.org/10.1016/j.tate.2020.103030.

Mullis, I. V. S., Martin, M., \& Tom, L. (2016). 20 Years of TIMSS: International Trends in Mathematics and Science Achievement Curriculum and Instruction. International Association for the Evaluation of Educational Achievement (IEA).

NCTM. (2014). Principles to Actions: Ensuring Mathematical Success for All. NCTM.

Nurhusain, M. (2017). Impact Analysis of Cooperative Learning Model Application Type Two Stay Two Stray (Tsts) Toward Learning Outcomes of Mathematics. JPMI (Jurnal Pendidikan Matematika Indonesia), 2(2), 46. https://doi.org/10.26737/jpmi.v2i2.220.

Odell, B., Gierl, M., \& Cutumisu, M. (2021). Testing measurement invariance of PISA 2015 mathematics, science, and ICT scales using the alignment method. Studies in Educational Evaluation, 68. https://doi.org/10.1016/j.stueduc.2020.100965.

Ozdag, H., \& Aygor, N. (2012). Undergraduate students 'performances in linear algebra: factorization of a determinant of $n * n$ dimensional matrices. 46, 125-129. https://doi.org/10.1016/j.sbspro.2012.05.080.

Piyayodilokchai, H., Panjaburee, P., Laosinchai, P., Ketpichainarong, W., \& Ruenwongsa, P. (2013). A 5E Learning Cycle Approach-Based, Multimedia-Supplemented Instructional Unit for Structured Query Language. Educational Technology \& Society, 16(4), 146-159. https://doi.org/10.2307/jeductechsoci.16.4.146.

Plaikoil, A. K. S., Pujani, N. M., \& Tika, I. N. (2019). The Effect of 5E Learning Cycle Model on Problem Solving Ability in Terms of Student Numerical Ability. Proceeding of International Conference on Fundamental and Applied Research (ICFAR). https://doi.org/10.36002/icfar.v0i0.942.

Purwati, S. (2016). Pengaruh Pengetahuan Awal Terhadap Pemahaman Konsep Usaha dan Energi. Prosiding SNFA (Seminar Nasional Fisika Dan Aplikasinya).

Putra, F. Y., Nurkholifah, I., Subali, B., \& Rusilowati, A. (2018). 5E-Learning Cycle Strategy: Increasing Conceptual Understanding and Learning Motivation. Jurnal Ilmiah Pendidikan Fisika Al-BiRuNi, 7(2), 171-181. https://doi.org/10.24042/jipfalbiruni.v7i2.2898.

Qawasmeh, R. M., \& Syouf., A. A. A. (2017). The Effect of Using Computerized 5E's Learning Cycle Model on Acquiring Scientific Concepts among Fourth Graders. American Journal of Educational Research, 5(5), 579-587.

Scanlon, E., Anastopoulou, S., Kerawalla, L., \& Mulholland, P. (2011). How Technology Resources Can Be Used to Represent Personal Inquiry And Support Students' Understanding Of It Across Contexts. Journal of Computer Assisted Learning, 27(6), 516-529. https://doi.org/10.1111/j.1365-2729.2011.00414.x.

Simon, M. A. (2017). Explicating Mathematical Concept and Mathematical Conception as Theoretical Constructs. Educational Studies in Mathematics, 94(2), 117-137. https://doi.org/10.1007/s10649-016-9728-1.

Smith, M., Bill, V., \& Raith, M. L. (2018). Promoting a Conceptual Understanding of Mathematics. Mathematics Teaching in the Middle School, 24(1), 36-43. https://www.nctm.org/Publications/Mathematics-Teaching-in-Middle-

School/2018/Vol24/Issue1/Promoting-a-Conceptual-Understanding-of-Mathematics/.

Sukardjo, M., \& Salam, M. (2020). Effect of Concept Attainment Models and Self-Directed Learning (SDL) on Mathematics Learning Outcomes. International Journal of 
Instruction, 13(3), 275-292. https://doi.org/https://doi.org/10.29333/iji.2020.13319a.

Suryabrata, S. (2014). Metodologi Penelitian. PT. Raja Grafindo Persada.

Tuna, A., \& Kaçar, A. (2013). The Effect of 5E Learning Cycle Model in Teaching Trigonometry on Students' Academic Achievement and the Permanence of Their Knowledge. International Journal on New Trends in Education and Their Implications, 4(1). http://www.ijonte.org/FileUpload/ks63207/File/07.tuna.pdf.

Widodo, S., \& Kartikasari, K. (2017). Pembelajaran Pemecahan Masalah Matematis Siswa Sekolah Dasar Dengan Model Creative Problem Solving (Cps). Prisma, 6(1). https://doi.org/10.35194/jp.v6i1.28.

Xin, Y. P., Park, J. Y., Tzur, R., \& Si, L. (2020). The impact of a conceptual model-based mathematics computer tutor on multiplicative reasoning and problem-solving of students with learning disabilities. The Journal of Mathematical Behavior, 58. https://doi.org/10.1016/j.jmathb.2020.100762.

Yilmaz, M., Yildirim Sari, H., \& Daghan, Ş. (2020). An exploratory study of intercultural effectiveness scale in nursing students. Heliyon, 6(2). https://doi.org/10.1016/j.heliyon.2019.e02769. 